\title{
Sugarcane Biopolymer as a Guide Tube in the Regeneration of Peripheral Nerves in Rats
}

\author{
Biopolímero de Caña de Azúcar como Tubo Guía en \\ la Regeneración de Nervios Periféricos en Ratones
}

\begin{abstract}
Ivson Bezerra da Silva ${ }^{1}$; Deniele Bezerra Lós ${ }^{2}$; Rodrigo Fragoso de Andrade ${ }^{3}$; Carla do Couto Soares Maciel ${ }^{4}$; Célia Maria Machado Barbosa de Castro ${ }^{5}$; José Lamartine de Andrade Aguiar ${ }^{6}$ \& Silvia Regina Arruda de Moraes ${ }^{7}$
\end{abstract}

DA SILVA, I. B.; LÓS, D. B.; DE ANDRADE, R. F.; MACIEL, C. C. S.; DE CASTRO, C. M. M. B.; AGUIAR, J. L. A. \& DE MORAES, S. R. A. Sugarcane biopolymer as a guide tube in the regeneration of peripheral nerves in rats. Int. J. Morphol., 37(1):289295, 2019.

SUMMARY: Peripheral nerve regeneration is a serious clinical problem. The goal of this work was to evaluate comparatively a biopolymer tube of sugarcane with an expanded polyethylene tube as a tube guide in peripheral nerve regeneration. Fourteen male albino Wistar rats were used, separated into three different groups: control (CG), lesion + polyethylene tube (PG) and lesion + sugarcane biopolymer (SBG). At 60 days old, animals from the PG and SBG underwent surgery for tubulization of the sciatic nerve, and 60 days after the injury they were sacrificed for collection of the nerve. In the analysis of the number of nerve fibers, a smaller number was seen in the PG and SBG groups compared to the CG, no difference was seen between the PG and SBG groups ( $<<0.05)$. With regard to the number of blood vessels, the SBG group had a larger number than the CG and PG groups $(\mathrm{p}<0.05)$. The SBG also presented increase on axonal diameter and $\mathrm{G}$-ratio compared to $\mathrm{PG}(\mathrm{p}<0.05)$. Taken together these data revealed that biopolymer tube favors a suitable environment for peripheral nerve regeneration.

KEY WORDS: Nerve regeneration; Biomaterials; Biopolymer; Sugarcane; Sciatic nerve.

\section{INTRODUCTION}

Peripheral nerves are commonly exposed to physical injuries that should case significant sensory and motor deficits in the affected individuals, as well as pain and other unpleasant sensations, resulting in devastating impact on patients' quality of life. Traumatic injuries to the nervous system affect millions of people worldwide every year and these severe injuries can cause substantial nerve defects (Gu et al., 2014). After axonal injury, a series of physiological events occurs in the injured tissue, in order to re-establish a functional connection between the nerve and target organ. This repair process involves several factors such as inflammatory cells recruitment, proliferation of Schwann cells and release of pro-regenerative factors and products of the extracellular matrix, which provide a growpromoting microenvironment for regenerating axons (RibeiroResende et al., 2009). da Silva et al. (2014) demonstrated that Schwann cells interact via the p75 neural growth factor (NGF) receptor, inducing regeneration after nerve axotomy. However, this process may be impaired when complete nerve transection occurs leading to the impossibility to get axonal regeneration (Raimondo et al., 2011). In these cases, reconstructive surgery is required as a therapeutic management to achieve nerve regeneration and function restoration.

Several options and techniques have been developed over the years, each with specific indications and limitations. The tubulization technique seems to favor a greater orientation of the neural stumps and the concentration of neurotrophic factors released by nerve ends during the regenerative process (Geuna et al., 2014).

\footnotetext{
${ }^{1}$ Physiotherapist, Adjunct Professor in Department of Morphology - Human Anatomy, Universidade Federal da Paraíba, João Pessoa, Brazil.

${ }^{2}$ Physiotherapist, Postdoctoral fellow at the Instituto Aggeu Magalhães IAM/Fiocruz, Brazil.

${ }^{3}$ Physiotherapist, Adjunct Professor in Department of Physiotherapy at Universidade Federal do Ceará, Fortaleza, Brazil.

${ }^{4}$ Biologist, Professor at Universidade de Fortaleza, Fortaleza, Brazil.

${ }^{5}$ Physician, Full Professor in Department of Tropical Medicine at Universidade Federal de Pernambuco, Brazil.

${ }^{6}$ Physician, Full Professor in Department of Surgery at Universidade Federal de Pernambuco, Recife, Brazil.

${ }^{7}$ Physiotherapist, Full Professor in Department of Anatomy at Universidade Federal de Pernambuco, Recife, Brazil.
} 
Several materials have been used to create the optimal tubular structure for a nerve conduit. Natural biomaterials such as autologous nerve grafts or muscles, vein and tendons have the disadvantage of causing donor site morbidity, sensory loss or neuroma formation (Muheremu \& Ao, 2015). For this reason, artificial nerve guide could be used to bridge the gap (Raimondo et al.). Non-degradable synthetic materials, such as silica gel, silicone and polyethylene were one of the first alternatives to replace the natural biomaterials (Muheremu \& Ao). However, the main disadvantage of these conduits, is that they have to be explanted after integration because can cause an excessive scar tissue, producing chronic compression of the nerve and inhibiting nerve functional recovery ( $\mathrm{Gu} e t$ $a l$.). Furthermore, additional surgical is required to remove the non-degradable nerve conduits. For this reason, research in the last decade has intensified, in an attempt to analyze biocompatible materials and capable of bio-absorption for use as guide tubes for bridging to axonal growth (Albuquerque $e t$ al., 2015).

An acellular exopolysaccharide biopolymer has been produced from sugarcane molasses through of bacterial synthesis (Zoogloea sp) in the Carpina Experimental Station of Sugarcane/ Rural University of Pernambuco/Brazil, since 1990, composed of different monosaccharides (PatersonBeedle et al., 2000).

The sugarcane biopolymer is a very competitive polymer compared to other similar materials and can be considered as a promising biomaterial for tissue engineering due to high elasticity, resistance to traction, good mechanical flexibility, low toxicity, low production cost, biocompatibility and capability of integration with different living tissues (Pita et al., 2015).

In experimental studies the application of sugarcane biopolymer has shown adequate response in reconstruction of tympanic membrane (Mayer et al., 2011), fold vocal (Vasconcelos et al., 2015), osteochondral defect (Albuquerque et al.), patch vascular (Marques et al., 2007), eviscerated eyes (Cordeiro-Barbosa et al., 2012) and bladder graft (Carvalho Junior et al., 2012). However, there are not records in scientific literature on the use this biopolymer in the treatment of nerve injuries.

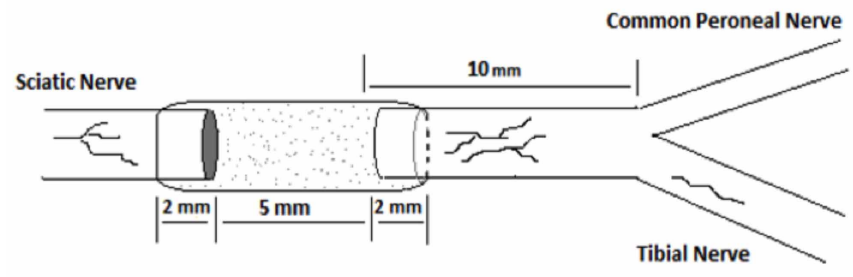

Fig. 1. Surgical scheme. The tubulization procedure with polyethylene or biopolymer tubes, rat sciatic nerve left a $5 \mathrm{~mm}$ gap.
The present study tested the feasibility of using a sugarcane biopolymer artificial for application as guide tubes in the peripheral nerve regeneration process, after experimental neurotomy.

\section{MATERIAL AND METHOD}

All surgical procedures and protocols were performed in accordance with the Ethical Principles in Animal Research set forth by the Brazilian College of Animal Experimentation and were approved by the committee in animal experimentation of UFPE (\#004721/2007-95).

Experimental Groups. A total of fourteen Wistar male rats weighing approximately 250-280 g were used in this study. The animals were kept under temperature and lightcontrolled environment $\left(23{ }^{\circ} \mathrm{C} \pm 2{ }^{\circ} \mathrm{C}\right.$ on a $12 \mathrm{~h} \mathrm{light/dark}$ cycle at $60 \%$ humidity) housed in propylene plastic cages $(49 \times 34 \times 16 \mathrm{~cm})$ and were given free access to standard rat chow diet and water in the Experimental Vivarium of the Department of Anatomy - CCB/UFPE. The animals were randomly divided and allocated tothree groups: Control Group $(\mathrm{CG}, \mathrm{n}=4)$; peripheral nerve lesion + Polyethylene Tubulization Group (PG, n=5); and peripheral nerve lesion + Sugarcane Biopolymer Tubulization Group (SBG, n=5).

Manufacture of biopolymer tube from sugarcane. Biopolymer tubes were made from a continuous surface film of an exopolyssacharide, a bioactive copolymer consisting of $87 \%$ glucose, $8.5 \%$ xylose, $1.68 \%$ ribose, $0.83 \%$ glucuronic acid, $0.82 \%$ mannose, $0.37 \%$ arabinose, $0.13 \%$ galactose, $0.01 \%$ rhamnose and $0.01 \%$ fucose obtained from sugar polymerization of sugarcane molasses by biotechnological means, as suggested by Paterson-Beedle et al. The wall of the tubes was formed of a single layer of film with $0.1 \mathrm{~mm}$ thickness and, to maintain standardized conditions for the regenerative process, the biopolymer tubes were manufactured with the same length $(9 \mathrm{~mm})$ and internal diameter $(2.3 \mathrm{~mm})$ as the polyethylene tubes. After their construction, the tubes were sterilized by gamma radiation to ensure the sterile nature of the material to be used in the surgical procedure.

Surgical procedure. When the rats were 60 days old they were anesthetized with a solution of $2 \%$ xylazine (Rompumâ - Bayer) and ketamine (Ketalarâ) intramuscularly in a volume of $0.2 \mathrm{ml}$ of solution for each $100 \mathrm{~g}$ of the body weight, the animals were pre-anesthetized ten minutes before the anesthesia with a solution of atropine $(0.044 \mathrm{mg} / \mathrm{Kg})$. After a trichotomy in the posterior region of the right paw, an incision was made in the skin and then the gluteus 
maximus and gluteus medius muscles were folded back to view the sciatic nerve.

Damage to the nerve was made at a distance of $1 \mathrm{~cm}$ above the bifurcation of the nerve, in order to standardize the location of nerve injury. The damage was reconstituted immediately, according to the experimental groups, with a sugarcane biopolymer tube or a polyethylene tube. In both cases, the neural stumps were completely introduced inside the lumen of the tube, separated by a distance of $5 \mathrm{~mm}$, producing a closed compartment (Fig. 1). The lumen of both tubes was filled with a mixture of matrigel (MatrigelTM BD Bioscience) (33\%) and saline solution (Lós et al., 2015).

The incision was closed in layers and, in the rats from control group (CG) the sciatic nerve was exposed but not was affected. Each animal was closely observed during the recovery time from anesthesia and after being returned to the cage they were carefully observed for $24 \mathrm{~h}$ (Fig. 2).

\section{Collection of Material and Histological Processing. Sixty} days after the initial nerve lesion, a new surgical procedure was performed, using the same guidelines for pre-anesthesia and anesthesia as the first procedure. After exposure of the sciatic nerve, a pre-fixation was performed with Karnowisky solution in situ. Newly formed nerve tissue in the central region of the tube was collected and sent for histological processing. After collection of the material, the animals were euthanized with an intracardiac injection of $1 \mathrm{ml}$ of potassium chloride $(10 \%)$.

The nerve fragments were fixed in solution $-2.5 \%$ glutaraldehyde and $4 \%$ paraformaldehyde in $0.1 \mathrm{M}$ sodium cacodylate (Sigma-Aldrich) buffer, ph 7.2 - for 24 h at 4 ${ }^{\circ} \mathrm{C}$. After this procedure, the fragments were washed with an aqueous solution of sodium cacodylate buffer and postfixed with a solution containing $1 \%$ osmium tetroxide for

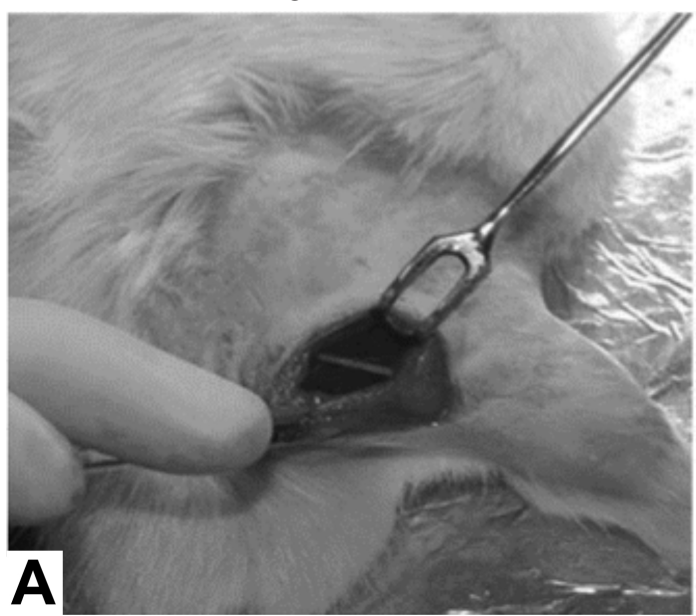

Fig. 2. Surgical procedure. A - Rat from control group - CG, B- Rat from biopolymer tubulization group - SBG.

90 min, at room temperature. Subsequently, the material was dehydrated in increasing concentrations of aqueous solutions of acetone and embedded in Epon 812 resin (Polysciences®).

Transverse semi-thin $(0.5 \mu \mathrm{m})$ sections of the sciatic nerve were obtained using, an ultramicrotome (ULTRACUP UCT, LEICA). The sections were stained with toluidine blue (1\%), a dye specific for lipid-rich structures, such as the myelin sheath.

Histomorphometric analysis. The images were captured by an optical microscope (Olympus - BX50, 1000x magnification), connected to a video camera (Samsung SHC-410 NAD) and a computer with the software application TV Tuner.

The program Mesurim Pro (Mesurim Pro $₫$ software version 3.4) was used to achieve the total quantification of blood vessels and the number of myelinated fibers and the program Image J (NIH, Bethesda) was used for measurement of diameter of myelinated fibers and axonal diameter. Then, thickness of the myelin sheath and g-ratio were calculated as shown below.

In A the myelin sheath thickness (MST) is calculated as fiber diameter subtracted of axonal diameter divided by 2 and in B the g-ratio correspond to axonal diameter divided by fiber diameter value.

Statistical analysis. The figures were created and statistical analysis was done by GraphPad Prism 5.0. The data are expressed as mean \pm standard deviation (SD), using $95 \%$ as the confidence level and the value of $n$ is the number of animals used in each experimental group. The results were analyzed and compared using analysis of variance (oneway ANOVA) followed by Tukey's post hoc test.

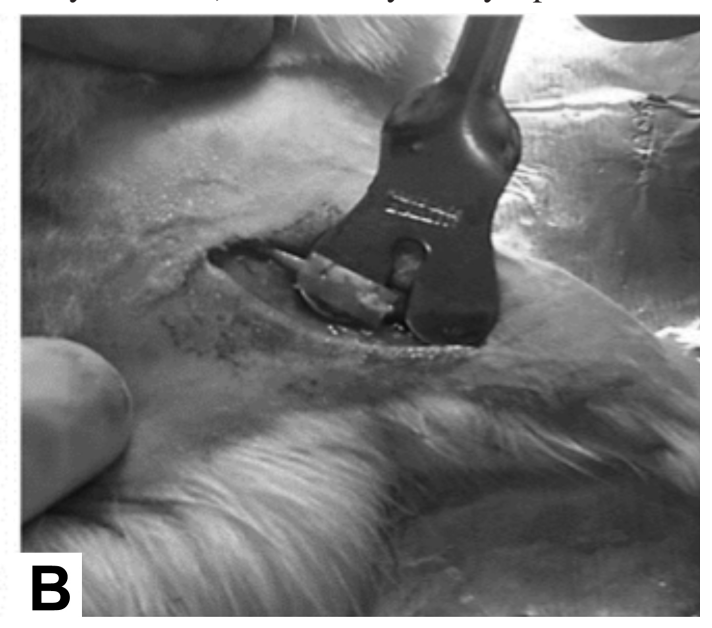




\section{RESULTS AND DISCUSSION}

Figure 3 show the cross section of sciatic nerve stained by toluidine blue to Control Group (a), Polyethylene Group (b) and Sugarcane Biopolymer Group (c). The histomorphometric analysis of regenerated nerve shows no difference in the number of myelinated fibers among groups (Fig. 3e). However, relating the nerve cross-sectional area has identified that the density of myelinated fibers was reduced in polyethylene and biopolymer groups compared to $\mathrm{CG}$ (Fig. 3d).

It was similar in density and diameter of myelinated fibers in addition to the thickness of the myelin sheath of polyethylene and biopolymer groups. However, the group receiving the biopolymer sugarcane showed a greater number of vessels (Fig. 3f), axonal diameter and g-ratio compared to polyethylene group (Fig. 4). These data demonstrate that the biopolymer tube favors a suitable environment for peripheral nerve regeneration.

The first tests for evaluation of the potential for clinical application of a new material are the cytotoxicity tests. It is known that the biocompatibility of materials used in implants is based on the inflammatory response of the host, and, according to Castro et al. (2004), in an in vitro study, it was shown that the biopolymer from sugarcane presents low cytotoxicity, which allows this material to be used as a substitute for various biological tissues (Coelho et al., 2002; Marques et al.). In a study of in vivo biocompatibility, the biopolymer proved appropriate as to its compatibility and tolerability for a specific application, such as urethral support, or slings, in the treatment of urinary incontinence in dogs (Braga-Silva et al., 2006).

Freitas \& Flores (2007), in a review article, reported the use of artificial tubes of different types of synthetic materials such as cellulose, plastic, silicone, gelatin and inert metals as a guide for peripheral nerve regeneration. However, these materials are not widely used, because they can promote an inflammatory and fibrotic reaction at the site of injury, thus producing chronic compression of the nerve. In addition, these materials require another surgical procedure for removal after neural regeneration, leaving the patient vulnerable to new nerve injury. In this way, the research has intensified for materials that are biodegradable and biocompatible to serve as substitute of biological tissues (Klemm et al., 2001).

The biopolymer from sugarcane was originally synthesized in 1990, at the Sugarcane Experimental Station in Carpina, a town in the Zona da Mata region of Pernambuco in a research center of the Universidade Federal Rural de Pernambuco - UFRPE. This biopolymer is an
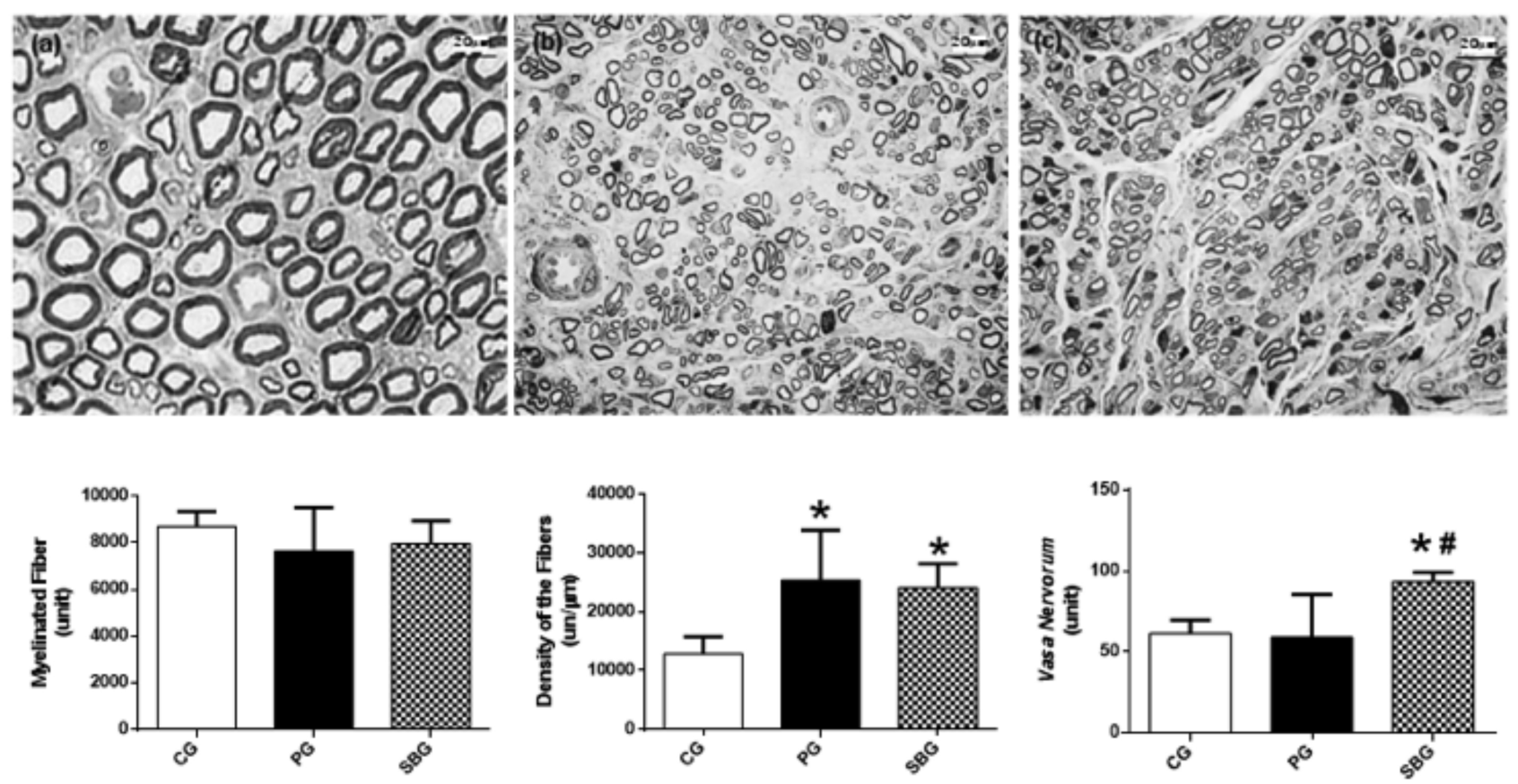

Fig. 3. Cross section of sciatic nerve stained by toluidine blue to Control Group (a), Polyethylene Group (b) and Sugarcane Biopolymer Group (c). Bar: 10mm. Magnification: 1000x. Quantification of density of the fiber (d), quantification of myelinated fiber (e) and quantification of vasa nervorum (f) in CG (Control Group), PG (Polyethylene Group) and SBG (Sugarcane Biopolymer Group). The results are expressed as mean $\pm \mathrm{SD}$. $* \mathrm{p}<0.05$ vs $\mathrm{CG}$; $\# \mathrm{p}<0.05$ vs PG. 

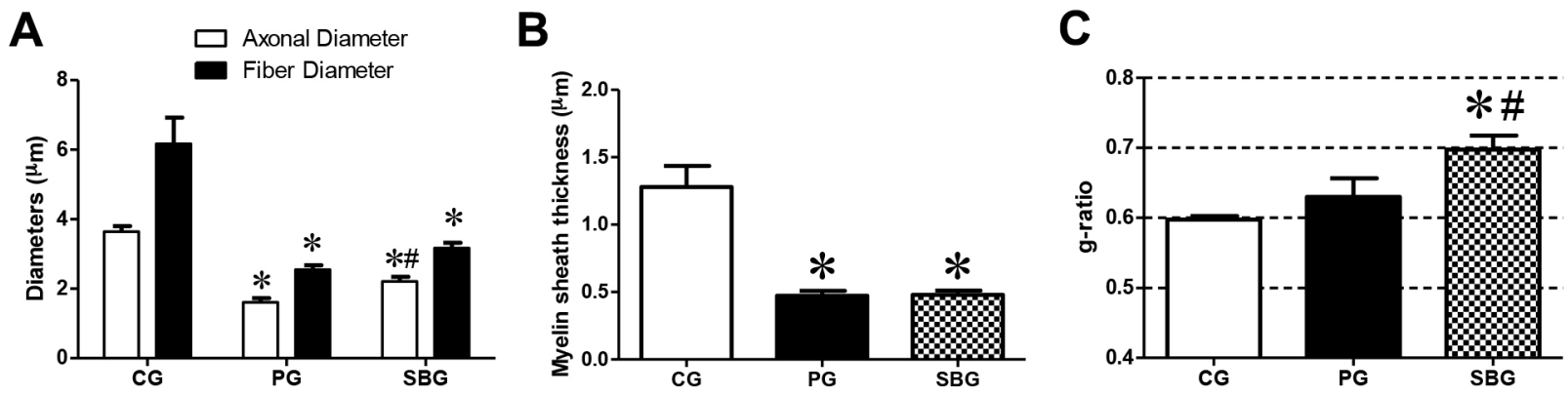

Fig. 4. Quantification of axonal diameter and fiber diameter (a). Myelin sheath thickness (b). G-ratio (c). CG (Control Group); PG (Polyethylene Group); SBG (Sugarcane Biopolymer Group). The results are expressed as mean \pm SD. *p<0.05 vs CG; \#p<0.05 vs PG.

exopolyssacharide obtained by bacterial synthesis of Zoogloea sp., from sugarcane molasses (Paterson-Beedle et al.).

In the literature, it is possible to find studies that tested the use of the sugarcane biopolymer as a substitute for some biological tissues. Coelho et al. noted that there was an increase of granulation tissue, infection control and decrease in healing time, concluding that the biopolymer contributes to the healing process, and may be used for the healing of cutaneous injuries.

Another study which examined naturally infected cutaneous injuries concluded that the sugarcane biopolymer can be used in the treatment of skin disorders because it controls the infection by a bacteriostatic or bactericidal effect, and due to its low cost and simple application.

Marques et al. have already shown that biopolymer membrane is able to be a suitable vascular substitute, when used in the form of patches of femoral arteries and femoral vein in dogs. Mayer et al., performing a study of tympanic bulla in rats, concluded that the biopolymer is biocompatible with this biological tissue, being completely absorbed by the tympanic bulla. The authors also concluded that the biopolymer membrane presents features that do it possible to be used as a graft in ear surgery.

As seen previously, the sugarcane biopolymer, being in the form of membranes, surgical dressings or slings, has been widely used in several studies (Coelho et al.; Marques et al.; Mayer et al.). However, until now, no study has been found in the literature that uses this biopolymer to repair nerve damage.

According to de Ruiter et al. (2009), among the features that a material must present in order to be used as a guide in the regenerative process of peripheral nerve, its permeability and flexibility stand out. Laboratory tests have shown that the sugarcane biopolymer is not soluble, but incorporates water, which can facilitate the transposition of water-soluble components, as well as promote the flexibility of the material.

In the present study, the amount of myelinated fibers, 60 days after nerve injury, was smaller in both experimental groups when compared with the $\mathrm{CG}(\mathrm{p}<0.05)$, however, there was no difference in the number of fibers comparing polyethylene tubes with biopolymer tubes.

One study assessed the nerve fibers regenerated in a postoperative period less than in our study showed a greater number of fibers when compared to the control group (Sobral et al., 2008). These results reflect the behavior of injured axons, as these axons send 2 to 3 shoots toward the distal stump during the initial phase of regeneration. For this reason, analyses carried out within a period less than 30 days post-injury presents a greater amount of nerve fibers than the analyses carried out after a longer post-injury period (Fawcett \& Keynes, 1990).

The absence of difference in the number of nerve fibers observed in the experimental groups (PG and SBG) signals a good biocompatibility response of the biopolymer tube with peripheral nerve tissue, showing similar behavior in two types of materials during the healing process.

With regard to the greater number of blood vessels observed in animals belonging to the group that used the biopolymer tube (SBG), this finding is possibly due to the ability of the biopolymer to promote an early exudate, which does not negatively influence the final result of nerve regeneration. This had already been reported by Mayer $e t$ al., when the biopolymer was compared to autologous fascia in the tympanic bulla of rats. These authors described the ability of the biopolymer to increase the exudate, reporting that in the early days after its implantation in biological tissues, there was an intense inflammation, but later, with 
the passage of time, there was a decrease in the inflammatory process. However, the analysis of nerve fragments performed sixty days after injury did not show permanent signs of the inflammatory process, since that process is characteristic of the first days after nerve injury, being able to generate angiogenesis, featuring the development of new blood vessels from pre-existing capillaries (Fechine-Jamacaru et al., 2005).

\section{CONCLUSION}

On the basis of the results obtained with the experimental model used, the sugarcane biopolymer appears to be a suitable material as a guide tube to be used in the regenerative process after peripheral nerve injury. In addition, the biopolymer did not interfere in the regenerative process (from a histological point of view), showing itself as a biocompatible material, with low cost and easy manipulation.

Other studies must be conducted to further clarify the association of the sugarcane biopolymer tube and peripheral nerve regeneration with regard to a functional evaluation of the newly formed nerve tissue. Such work would be a necessary precursor to future research aimed at the use of this biopolymer in clinical trials with humans, contributing to programs aimed at neurofunctional rehabilitation.

\section{ACKNOWLEDGEMENTS}

The authors are grateful to CAPES and FACEPE for the financial support of this study; da Silva IB was recipient of a scholarship from the FACEPE; Lós DB and Andrade, RF were recipients of a scholarship from CAPES; to CETENE (Centro de Tecnologias Estratégicas do Nordeste) and Mr. Rafael Padilha for technical support in microscopy and to the BVSc. Edeones França and MSc. Adriana Cruz.

DA SILVA, I. B.; LÓS, D. B.; DE ANDRADE, R. F.; MACIEL, C. C. S.; DE CASTRO, C. M. M. B.; AGUIAR, J. L. A. \& DE MORAES, S. R. A. Biopolímero de caña de azúcar como tubo guía en la regeneración de nervios periféricos en ratones. Int. J. Morphol., 37(1):289-295, 2019.

RESUMEN: La regeneración nerviosa periférica es un problema clínico grave. El objetivo de este trabajo fue evaluar comparativamente un tubo de biopolímero de caña de azúcar con un tubo de polietileno expandido, como guía de tubo en la regeneración de nervios periféricos. Se utilizaron dieciocho ratas Wistar albinas macho, separadas en tres grupos: control (CG), lesión + tubo de polietileno (PG) y lesión + biopolímero de caña de azúcar (SBG). A los 60 días de edad, los animales del PG y SBG fueron sometidos a una cirugía para la tubulización del nervio ciático, y 60 días después de la lesión fueron sacrificados para la recolección del nervio. En el análisis del número de fibras nerviosas, se observó un número menor en los grupos PG y SBG en comparación con el CG; no se observaron diferencias entre los grupos PG y SBG ( $\mathrm{p}<0,05)$. Con respecto al número de vasos sanguíneos, el grupo SBG tuvo un número mayor que los grupos CG y PG ( $\mathrm{p}<0,05)$. El SBG también presentó un aumento en el diámetro axonal y la proporción $\mathrm{G}$ en comparación con PG ( $\mathrm{p}<0,05)$. En conjunto, estos datos revelaron que el tubo de biopolímero favorece un entorno adecuado para la regeneración de nervios periféricos.

PALABRAS CLAVE: Regeneración nerviosa; Biomateriales; Biopolímero; Caña de azúcar; Nervio ciático.

\section{REFERENCES}

Albuquerque, P. C.; Aguiar, J. L.; Pontes Filho, N. T.; Mello, R. J.; Olbertz, C. M.; Albuquerque, P. E.; Paz, S. T.; Santo, A. H. \& Maia, C. S. A comparative study of the areas of osteochondral defects produced in femoral condyles of rabbits treated with sugar cane biopolymer gel. Acta Cir. Bras., 30(11):770-7, 2015.

Braga-Silva, J.; Gehlen, D.; Roman, J. A.; Menta, C.; Atkinson, E. A.; Machado, D. C.; Viezzer, C.; Barbosa, G. L.; Baes, C. V. W.; Silva, V. D. \& da Costa, J. C. Bone marrow stem cells and platelet-rich plasma effects on nervous regeneration and functional recovery in an acute defect model of rats peripheral nerve. Acta Ortop. Bras., 14(5):273-5, 2006.

Carvalho Junior, A. M.; Santos, M. M.; Barkokébas, B. B.; Andrade Aguiar, J. L.; Lima, S. V. \& Dambros, M. Characterization of the deposition of collagen fibers and lithogenic potential in bladder of rats submitted to a sugar cane biopolymer graft. Int. Braz. J. Urol., 38(4):544-51, 2012.

Castro, C. M. M. B.; Aguiar, J. L. A.; Melo, F. A. D. \& Silva, W. T. F. Citotoxicidade de biopolímero de cana-de-açúcar. An. Fac. Med. Univ. Fed. Pernamb., 49(2):119-23, 2004.

Coelho, M. C. O. C.; Carrazoni, P. G.; Monteiro, V. L. C.; Melo, F. A. D.; Mota, R. A. \& Tenório Filho, F. Biopolímero produzido a partir da cana-de-açúcar para cicatrização cutânea. Acta Cir. Bras., 17(Suppl. 1):11-3, 2002.

Cordeiro-Barbosa, F. de A.; Aguiar, J. L.; Lira, M. M.; Pontes Filho, N. T. \& Bernardino-Araújo, S. Use of a gel biopolymer for the treatment of eviscerated eyes: experimental model in rabbits. Arq. Bras. Oftalmol., 75(4):267-72, 2012

da Silva, T. F.; Eira, J.; Lopes, A. T.; Malheiro, A. R.; Sousa, V.; Luoma, A.; Avila, R. L.; Wanders, R. J.; Just, W. W.; Kirschner, D. A.; Sousa, M. M. \& Brites, P. Peripheral nervous system plasmalogens regulate Schwann cell differentiation and myelination. J. Clin. Invest., 124(6):2560-70, 2014

de Ruiter, G. C.; Malessy, M. J.; Yaszemski, M. J.; Windebank, A. J. \& Spinner, R. J. Designing ideal conduits for peripheral nerve repair. Neurosurg. Focus, 26(2):E5, 2009.

Fawcett, J. W. \& Keynes, R. J. Peripheral nerve regeneration. Annu. Rev. Neurosci., 13:43-60, 1990.

Fechine-Jamacaru, F. V.; Fechine Júnior, J. U. \& de Moraes Filho, M. O. Modelo de angiogênese inflamatória em córnea de coelho induzida pela cauterização alcalina pontual. Acta Cir. Bras., 20(1):64-73, 2005. 
Freitas, T. da S. \& Flores, L. P. Uso da técnica de tubulização para o reparo de lesões do sistema nervoso periférico. Arq. Bras. Neurocir., 26(1):16-23, 2007.

Geuna, S.; Tos, P.; Titolo, P.; Ciclamini, D.; Beningo, T. \& Battiston, B. Update on nerve repair by biological tubulization. J. Brachial Plex. Peripher. Nerve Inj., 9:3, 2014.

Gu, X.; Ding, F. \& Williams, D. F. Neural tissue engineering options for peripheral nerve regeneration. Biomaterials, 35(24):6143-56, 2014.

Klemm, D.; Schumann, D.; Udhardt, U. \& Marsch, S. Bacterial synthesized cellulose - artificial blood vessels for microsurgery. Prog. Polym. Sci., 26(9):1561-603, 2001.

Lós, D. B.; Novaes, K. A.; de Miranda, F. B. C.; de Lira, K. D. S.; de Andrade, R. F. \& de Moraes, S. R. A. Regenerative capacity and histomorphometric changes in rat sciatic nerve following experimental neurotmesis. Int. J. Morphol., 33(2):777-81, 2015.

Marques, S. R. B.; Lins, E. M.; de Andrade Aguiar, J. L.; Albuquerque, M. C. S.; Rossiter, R. O.; Montenegro, L. T. \& Vieira, R. J. A new vascular substitute: femoral artery angioplasty in dogs using sugarcane biopolymer membrane patch - hemodynamic and histopathologic evaluation. J. Vasc. Bras., 6(4):309-15, 2007.

Mayer, D. L.; Araújo, J. G.; Leal, M. de C.; Caldas Neto, S. da S.; Ataíde, R. F. \& Mello, R. J. Sugarcane biopolymer membrane: experimental evaluation in the middle ear. Braz. J. Otorhinolaryngol., 77(1):4450, 2011.

Muheremu, A. \& Ao, Q. Past, present, and future of nerve conduits in the treatment of peripheral nerve injury. Biomed Res. Int., 2015:237507, 2015.

Paterson-Beedle, M.; Kennedy, J. F.; Melo, F. A. D.; Lloyd, L. L. \& Medeiros V. A cellulosic exopolysaccharide produced from sugarcane molasses by a Zoogloea sp. Carbohydr. Polym., 42(4):375-83, 2000.

Pita, P. C.; Pinto, F. C.; Lira, M. M.; Melo, F. de A.; Ferreira, L. M. \& Aguiar, J. L. Biocompatibility of the bacterial cellulose hydrogel in subcutaneous tissue of rabbits. Acta Cir. Bras., 30(4):296-300, 2015.

Raimondo, S.; Fornaro, M.; Tos, P.; Battiston, B.; Giacobini-Robecchi, M. G. \& Geuna, S. Perspectives in regeneration and tissue engineering of peripheral nerves. Ann. Anat., 193(4):334-40, 2011.

Ribeiro-Resende, V. T.; Pimentel-Coelho, P. M.; Mesentier-Louro, L. A.; Mendez, R. M.; Mello-Silva, J. P.; Cabral-da-Silva, M. C.; de Mello, F. G.; de Melo Reis, R. A. \& Mendez-Otero, R. Trophic activity derived from bone marrow mononuclear cells increases peripheral nerve regeneration by acting on both neuronal and glial cell populations. Neuroscience, 159(2):540-9, 2009.

Sobral, L. L.; Oliveira, L. S.; Takeda, S. Y. M.; Somazz, M. C.; Montebelo, M. I. L. \& Teodori, R. M. Immediate versus later exercises for rat sciatic nerve regeneration after axonotmesis: histomorphometric and functional analyses. Rev. Bras. Fisioter, 12(4):311-6, 2008.

Vasconcelos, S. J.; Leão, R. A.; Bernardino-Araújo, S.; Lira, M. M. \& Tsuji, D. H. Effect of sugarcane biopolymer in vocal fold of rabbits. Comparative study with calcium hydroxyapatite. Acta Cir. Bras., 30(3):186-93, 2015.
Corresponding author:

Sílvia Regina Arruda de Moraes Universidade Federal de Pernambuco - UFPE

Departamento de Anatomia

Av. Professor Moraes Rego, s/n

0670-420 - Recife - PE

BRAZIL

Email: sramoraes@gmail.com

Received: 11-07-2018

Accepted: 16-10-2018 